\title{
Empirical evidence on legal levers aimed at addressing child maltreatment
}

\author{
Lindsey M. Eldred ${ }^{\text {a,* }}$, Elizabeth J. Gifford ${ }^{\mathrm{b}}$ \\ a Duke University, Department of Economics, 213 Social Sciences Building, Box 90097, Durham, NC 27708, United States \\ ${ }^{\mathrm{b}}$ Center for Child and Family Policy, Duke University, Box 90545, Durham, NC 27708, United States
}

\section{A R T I C L E I N F O}

Article history:

Received 25 August 2015

Received in revised form 17 November 2015

Accepted 17 November 2015

Available online 18 November 2015

\section{Keywords:}

Child maltreatment

Legal interventions

Evidence

Empirical legal research

Law

\begin{abstract}
A B S T R A C T
Law is a powerful tool for combatting public health issues. This article reviews existing empirical research on the effect of eight legal levers on outcomes related to child maltreatment. Laws created with the intent to address child maltreatment are often enacted without empirical basis. Further, following implementation, there is little empirical research on whether such statutes reduce or deter child maltreatment and improve child outcomes. This is in part due to the difficulty in studying the effects of a specific statute on measurable child outcomes.
\end{abstract}

(c) 2015 Elsevier Ltd. All rights reserved.
Law is a powerful tool for combatting public health issues (Mello, Studdert, \& Brennan, 2006; Mensah et al., 2004). Public health triumphs are credited to law changes-including reductions in morbidity and mortality from smoking (Levy, Benjakul, Ross, \& Ritthiphakdee, 2008) and motor vehicle accidents (Foss, Feaganes, \& Rodgman, 2001; Harper, Strumpf, Burris, Smith, \& Lynch, 2014; Mannix et al., 2012; Masten, Foss, \& Marshall, 2011). Laws influence behavior, support adoption of best practices, and alter the resources available to address an issue (Burrus et al., 2010). Despite the large-scale impact that the law can have, there is relatively limited empirical inquiry into how laws affect child abuse and neglect (maltreatment), or even on the juvenile dependency process more generally (Summers, Dobbin, \& Gatowski, 2008). While scholars have examined the impact of federal child protection laws on state and local laws and practices (Davidson, 1999), research on specific state statutes and actual impact on a case level is lacking.

This article reviews the published empirical literature on eight legal levers designed to prevent and deter child maltreatment: mandatory reporting, family drug treatment courts, central registries for child abuse, corporal punishment, exposure to domestic violence as child abuse, failure to protect, alternative response, and representation of children in child maltreatment proceedings. We seek to answer

\footnotetext{
* Corresponding author.

E-mail addresses: lindsey.eldred@duke.edu (L.M. Eldred), beth.gifford@duke.edu (E.J. Gifford).
}

whether the legal mechanisms reviewed are effective in preventing or deterring child maltreatment.

\section{Constitutional framework}

Child maltreatment laws operate under a framework created by the United States Constitution. Two conflicting objectives operate in this framework, family autonomy versus surveillance of child well-being (Dingwall, Eekelaar, \& Murray, 1995). There are two protections afforded by the constitution that are most relevant to our discussion. The first is parental rights. In the United States, the Supreme Court has deemed the rights of a parent to conceive and raise one's children as essential (Meyer v. Nebraska, 262 U.S. 390, 262 U.S. 399 (1923)) and protected by the constitution (Wallace \& Pruitt, 2012; U.S. CONST. amend XIV, Section 1). The U.S. Supreme Court has stated that the private interest of a parent "undeniably warrants deference and, absent a powerful countervailing interest, protection." (Stanley v. Illinois, 405 U.S. 645, 651 (1972)). States have instituted legislative and procedural protections for parental rights, in particular custody and termination of parental rights. Child protective services agencies must operate within these protections. Removal of a child from the home requires state agencies to evaluate the risk in the home. When a risk level that is set by the state is present, removal is justified (Wallace \& Pruitt, 2012). At a constitutional level, government intervention into the rights of parents to care for their children can only occur with due process, 
which, in the United States, generally means a fair hearing and legal representation (Duquette, 1997).

The second right important to our discussion is the right to follow a chosen profession. The Supreme Court has determined this right falls under the liberty and property concepts of the Fifth Amendment of the U.S. Constitution. In order to deny an individual the right to work in a particular profession, there must be due process, as guaranteed by the Fifth and Fourteenth Amendments. This is relevant to our discussion of central registries as placement on these registries frequently prevents an individual from working with children, e.g., teacher, coach, or daycare provider.

\section{Methodological difficulties in studying child maltreatment laws}

Legal levers related to child maltreatment are challenging to study. For one, law is difficult to measure. There is variation in the interpretation of laws, which leads to variation in how laws are implemented (Tremper, Thomas, \& Wagenaar, 2010). No central database documents when and where laws are enacted, implemented, enforced, or even repealed. Measuring maltreatment is also challenging as definitions vary by jurisdiction and context and may rely on subjective observation rather than validated measures (Whitaker, Lutzker, \& Shelley, 2005). Further, child maltreatment often occurs in private settings and frequently goes unreported. Data collection and quality confound true estimates of child maltreatment (Fallon et al., 2010). Therefore, evaluating the effect of laws, policies, and regulations is laborious and requires researchers to develop clever mechanisms to isolate the causal relationship.

This article reviews the empirical evidence on eight legal levers designed to affect child maltreatment within the child's family context. Some of these measures center on responding to child maltreatment (e.g., mandatory reporting, alternative response, legal representation). Other measures focus on preventing or deterring child maltreatment (e.g., family drug treatment courts, parental corporal punishment, exposure to domestic violence as child abuse, and failure to protect). Most studies use outcome measures such as reporting rates and compliance with the statute but not whether child health and welfare is improved or if perpetrator's behavior has changed.

\section{Review methodology}

Articles were identified through two major search engines, ISI Web of Science and Google Scholar. Web of Science is a standard search engine for identifying peer-reviewed studies. Google Scholar was preferred over PubMed because a previous study comparing both search engines revealed that articles found using Google Scholar were more relevant, had more citations, and were published in journals with higher impact scores (Nourbakhsh, Nugent, Wang, Cevik, \& Nugent, 2012). Inclusion criteria required that the study be published in a peer review outlet, focused on a U.S. sample, and examined the extent to which a change in the law or practice was causally related to change in maltreatment prevalence or incidence.

The eight legal levers were selected following discussions with several experts in child maltreatment research including a child psychologist, a physician, and an attorney specializing in poverty and family law. The levers were divided into primary and secondary prevention based on the intended goal of the lever. Primary prevention policies aim to reduce the victimization of children. For example, laws that ban corporal punishment can be viewed as primary prevention in that they aim to reduce the victimization of children. Such legal levers include corporal punishment, exposure to domestic violence as child abuse, and failure to protect. These laws aim to change the behavior of caretakers. Secondary prevention measures are those designed to improve detection of child maltreatment and protect children from future occurrences of abuse. Mandatory reporting laws are a secondary prevention tool and aim to change the reporting behavior of potential witnesses-notably medical and education professionals. Legal levers that fall in this category are mandatory reporting, central registries for child abuse, family drug treatment courts, alternative response, and representation of children in child maltreatment proceedings.

Search terms were entered for each of the eight legal levers in both Web of Science and Google Scholar. For mandatory reporting, we entered the following combinations of keywords: "mandatory reporting" AND ("child abuse" or "child maltreatment" or "child neglect"). Family drug treatment courts used, ("Drug Treatment Court" or "treatment court") AND "family;" alternative searches included "dependency treatment court." Central registries for child abuse we searched for the terms, "central registry" AND ("child abuse" or "abuse" or "child"). Searches for parental corporal punishment used ("corporal" or "corporal punishment") AND ("parent*" or "spanking"). Exposure to domestic violence searches used the terms "domestic violence" AND "exposure." Failure to protect searches used the terms "failure to protect." Searches for alternative response used the search terms, ("alternative response" or "differential response" or "multiple response") AND ("child abuse" or "child maltreatment" or "child neglect"). Legal representation used the search terms, "legal representation" AND ("children" or "child").

In addition to search engines, we conducted searches on specific journal websites, including, Child Abuse and Neglect, Child Maltreatment, Children and Youth Services Review, Child Welfare, and Protecting Children. We also used professional and governmental websites to search for relevant publications (National Quality Improvement Center on Differential Response in Child Protective Services, 2009, 2010, 2011, 2014; U.S. Department of Health and Human Services Administration for Children \& Families; University of Illinois at Urbana-Champaign Children and Family Research Center).

Finally, the bibliography of relevant articles was also reviewed to identify literature that had not appeared in these search engines. For each study that was identified as relevant to the legal lever, we documented details on the sample (e.g., make-up of treatment and control groups), outcome measures, and findings.

\section{Review of major findings: legal levers}

\subsection{Mandatory reporting}

The United States Children's Bureau drafted a model mandatory reporting statute in 1963 that required physicians to report children with serious physical injuries inflicted other than by accidental means; by the late 1960s, all fifty states had enacted reporting laws (Besharov, 1985). Mandatory reporting laws vary dramatically by state (Matthews \& Kenny, 2008). Specifically, as implemented, statutes fall into four main categories (1) who is identified as a mandatory reporter (e.g., law enforcement, health professionals, every adult), (2) what should be reported (e.g., physical abuse, signs of neglect, emotional abuse), (3) sanctions for violating the statute (e.g., fines, no penalty), and (4) identification and liability of the reporter (e.g., immunity, protection or release of the reporter's identity). As of 2013, professionals such as health care workers, educators, and childcare providers were mandated to report in all but two states (Child Welfare Information Gateway, 2014b). In some states, in addition to professionals, any person who suspects child abuse is mandated to report abuse (Child Welfare Information Gateway, 2014b).

The condition of the victim that triggers a report is another dimension by which states vary. States typically define the standard for making a report when an individual suspects, has reason to believe the child has been maltreated, or observes or has knowledge that a child is being subjected to conditions that would result in harm (Child Welfare Information Gateway, 2014b). In the same way, the repercussions for failing to report evidence of abuse, (e.g., fines, no penalty) vary by state. Failure to report is a criminal misdemeanor in 39 states, a felony in one state, and subject to a non-criminal fine in the remaining ten (Child Welfare Information Gateway, 2014b; Kim, Gostin, \& Cole, 2012). 
Inadequate resources and training are barriers to effectively implementing this policy, which aims to improve detection of child maltreatment and then relies on the ability of public agencies (largely social services) to address the issues. The primary concern is that mandatory reporting creates a large influx of reported maltreatment cases without a corresponding increase in the system's capacity to investigate and assess the situation, and address the needs of these children and families (Ainsworth, 2002; Melton, 2005; U.S. Advisory Board on Child Abuse and Neglect, 1990). A 1990 report by the U.S. Advisory Board on Child Abuse and Neglect promoted changes to address the current framework of social service investigations (U.S. Advisory Board on Child Abuse and Neglect, 1990). However, a subsequent report has not been conducted. Despite known potential shortcomings of the policy, there has been no systematic study of whether the way a mandatory reporting statute is implemented affects children's safety and well-being.

We found four empirical studies of the effects of mandatory reporting laws. Malcolm and Dugda (2012) examined whether mandatory reporting statutes for public officials crowded out private reports of abuse, and found that both public and private reports of abuse have both increased and crowding out was small and insignificant. The second study used county-level data from the U.S. National Child Abuse and Neglect Data System, and found that counties in states with mandatory reporting statutes for all adults have significantly higher rates of total and confirmed reports than counties in states without such statutes (Palusci \& Vandervort, 2014). In a third study, licensed psychologists were presented vignettes and asked how likely they were to report the case to authorities (Kalichman \& Brosig, 1992). Following their initial ratings, psychologists then read a statute from either Pennsylvania or Colorado to which they were randomly assigned and asked again their likelihood of reporting the cases. Pennsylvania's statute required professionals to report only if they had observed the suspected victim whereas Colorado's statute required professionals to report any suspicion of abuse. Findings indicated that the law's wording did not alter the clinicians' inclination to report a case or their certainty regarding whether the law required them to report. However, clinicians were more inclined to report a case after having just read the law.

A fourth study examined how state-level policies were correlated with the volume of referrals received and the quality of reports received in 44 states with mandatory reporting statutes (Steen \& Duran, 2014). This study examined state variation in three policies: (a) whether substance exposure among infants was identified as a form of child maltreatment; (b) whether the mandate to report was limited to professionals or included all citizens; and (c) whether the state treated failure to report as a criminal offense. None of these policy variations were related to the volume of reports or the quality of reports. This study also compared states based on the type of their reporting system: centralized, decentralized, or hybrid. Centralized reporting systems received referrals through a single statewide hotline; decentralized systems had multiple hotlines at the local level received referrals; and hybrid systems received referrals from both state and local sources. Results found that states with a hybrid system had significantly higher substantiated reports than states with decentralized systems. States with centralized systems screened-in a higher percentage of referred reports than states with decentralized or hybrid systems (Steen \& Duran, 2014). The authors suggest that the reporting system affected employee's decisions regarding investigations and assessments but did not affect an individual's decision to report. A major limitation to this study is the use of cross-sectional data.

What the literature lacks is a longitudinal examination of child wellbeing relative to specific methods of implementation and enforcement of mandatory reporting laws. In addition to studying process measures related to the volume and quality of the reports that agencies receive, research should examine how mandatory reporting laws affect children's access to quality services, are there common characteristics among reported individuals, and what is the effect of the report on the family. This is relevant because a criticism of mandatory reporting is that it potentially creates unmanageable caseloads. It is also important to know how many cases resulting in services were from mandatory reporting versus other public health interventions. Because mandatory reporting aims to decrease the number of cases that go unreported to authorities, states could track child fatalities among children who were never referred to CPS.

\subsection{Family drug treatment courts}

Drug treatment courts are a popular type of specialty court that treat a participant's addiction in order to reduce negative outcomes, such as criminal recidivism. Therapeutic jurisprudence has been used since the 1990s with the creation of adult drug treatment courts (Eckrich \& Loudenburg, 2012). Generally, drug treatment courts use intense monitoring through drug tests and regular court appearances as well as judicial attention and outside treatment services. Family drug treatment courts (FDTCs) are a type of drug treatment court that may be structured as civil or criminal. When they are part of the civil system, referrals come from social workers, probation officers or others involved with an at risk family. In contrast, when they are structured as part of the criminal justice system, referrals to the court often come from the defense or prosecuting attorney and result in either a reduced or deferred sentence. A parent may have already lost custody of their child and be working toward the "carrot" of reunification or, alternatively, the parent may maintain custody with the "stick" being losing custody. Family drug treatment courts are in place in 43 states (American University School of Public Affairs, 2012).

Existing literature on this topic considers two outcome measures, increase in reunification with parent and length of time in foster care. Of the two, there is more evidence that FDTCs increase reunification rates; nine studies found an increase in reunification for participants (Ashford, 2004; Boles, Young, Moore, \& DiPirro-Beard, 2007; Burrus, Mackin, \& Finigan, 2011; Chuang, Moore, Barrett, \& Young, 2012; Dakof et al., 2010; Gifford, Eldred, Vernerey, \& Sloan, 2014; Green, Furrer, Worcel, Burrus, \& Finigan, 2009; Green, Rockhill, \& Furrer, 2007b; Worcel, Furrer, Green, Burrus, \& Finigan, 2008). Several studies found reduced time spent in foster care for children of participants (Bruns, Pullmann, Weathers, Wirschem, \& Murphy, 2012; Burrus et al., 2011; Gifford et al., 2014; Green, Furrer, Worcel, Burrus, \& Finigan, 2007a; Worcel et al., 2008), although one study reported longer stays (Chuang et al., 2012) and another found the effect varied by court (Green et al., 2009). To date, long-term outcomes have not been evaluated. With the exception of one study that found no difference in the probability of a subsequent maltreatment report between FDTC participants and the treatment-as-usual group (Green et al., 2007a), no studies have examined whether children who were reunited with their parents after treatment had better long-term outcomes. Further, it is not known whether parents who enter FDTCs when they are able to maintain custody during treatment are more successful and/or their children have better outcomes.

Unlike many of the other legal interventions, existing research suggests family drug treatment courts positively affect children's outcomes. Previous studies focused on reunification rates and length of time in foster care. Research could be extended by examining additional benefits that children may experience from parental participation in a FDTC such as improved school performance and better health or mental health outcomes. A better understanding of how receipt of specific services, such as cognitive behavioral therapy, could contribute to the literature.

\subsection{Central registries for child abuse}

Central registries are state databases that contain information regarding alleged cases of child maltreatment (U.S. Department of Health and Human Services, 2011). These registries were created to assist in the identification and protection of abused and neglected 
children (Child Welfare Information Gateway, 2014a). Reports created from the registry are used to aid social service agencies in the investigation, treatment, and prevention of child abuse as well as serve as a resource for screening individuals who will work directly with children (Child Welfare Information Gateway, 2014a). The contents of the registry vary by state, but most contain the same basic information such as identifying information for the child, mother, and father, names of siblings, the harm to the child, the alleged perpetrator, and results of any investigations (Child Welfare Information Gateway, 2014a). Many states have adopted these local policies as state law; 40 states and the District of Columbia have such laws (U.S. Department of Health and Human Services, 2011).

Even though there has been widespread adoption, there is concern that these statutes do more harm than good as they are not designed to protect parents' due process rights. In California, a parent remains on the registry for ten years, even if the child maltreatment claim against them was unsubstantiated (Navid, 2011). States also vary dramatically in the standard of proof required to be placed on the registry; Maryland requires only "some credible evidence" while West Virginia requires a criminal conviction (Sherman, 2011). Further, future and current employers frequently use this registry in employment decisions, and some types of jobs are forbidden from hiring from this list (Sherman, 2011).

The effectiveness of this policy has not been fully tested to warrant the lack of procedural due process involved in placement on a child abuse registry, a point that critics cite as reason for reform (Miller, 2011; Sherman, 2011). ${ }^{1}$ However, child abuse registries do serve an important function in identifying vulnerable populations at risk of violence and quantifying that risk relative to the general population (Sabotta \& Davis, 1992).

Central registries serve two purposes that are each amenable to study. One purpose is to document perpetrators of child maltreatment and to restrict their access to children. To evaluate the effectiveness, perpetrators of child maltreatment who were and were not placed on central registries could be tracked in arrest and CPS records for victimizing children. Another goal of central registries is to better serve child victims and prevent re-victimization. Therefore, studies could track children who have been reported for maltreatment and whether they were placed on a central registry. Longitudinal surveys could also investigate whether placement on a central registry negatively affects parents' employability, and, in turn, children's outcomes on measures such as exposure to conflict in the home or material deprivation.

\subsection{Corporal punishment}

Legally, parental corporal punishment and child abuse are distinct behaviors. All states allow the use of parental corporal punishment in the discipline of a child (Davidson, 1997). Each state determines the limits of acceptable physical punishment; for example, 29 states define it as the use of reasonable force with an added qualifier that it must be appropriate, moderate, or necessary (Gershoff, 2002). However, corporal punishment has been repeatedly linked with abuse (Zolotor, 2014). While there is a trend toward banning corporal punishment in public settings, particularly in school and foster care settings, not all states have done so. As of 2003, 27 states and the District of Columbia had forbidden corporal punishment in schools while 37 states prohibited foster parents from spanking (Pollard, 2003). And, despite many states forbidding it in schools or foster care settings, parental corporal punishment is legal in all states.

The harms associated with parental corporal punishment include greater anti-social behavior (Grogan-Kaylor, 2004; Straus, Sugarman, \& Giles-Sims, 1997), disruptive behavior problems in children (Stormshak, Bierman, McMahon, Lengua, \& Conduct Problems

\footnotetext{
1 The constitution requires procedural due process when removing an individual's liberty or property interest (U.S. Const. amend. XIV).
}

Prevention Research Group, 2000), higher rates of anxiety disorders and substance abuse or dependence (Lansford et al., 2014; MacMillan et al., 1999), aggression toward parents (Brezina, 1999), abuse of significant others as adults (Simons, Lin, \& Gordon, 1998), and an increased likelihood of using corporal punishment against their own children (Gershoff, 2002). Additionally, there is evidence showing slower cognitive development for children subjected to corporal punishment (Straus \& Paschall, 2009). While there is a large body of evidence linking corporal punishment to negative outcomes for children, there is an equally large body of literature that finds no effect on anti-social behavior (Gunnoe \& Mariner, 1997). A meta-analysis of 88 studies conducted over 62 years using correlational evidence found parental corporal punishment was associated with a range of undesirable behaviors and experiences, including physical abuse, delinquency, and antisocial behavior (Gershoff, 2002). Another meta-analysis of 26 studies found that the detrimental child outcomes described above are not unique to corporal punishment itself except in instances where it is used predominantly or severely (Larzelere \& Kuhn, 2005).

While there have been numerous studies on the harms of corporal punishment by parents, there is no research in the United States on the effects of laws limiting its use. Twenty four countries, 19 of which are in Europe, have banned parental corporal punishment (Zolotor \& Puzia, 2010). A study following Sweden's ban found that Sweden's child abuse mortality rates had decreased in the years following the ban (Durrant, 1999). Declines in rates of corporal punishment were also found in Germany (Bussmann, 2004).

\subsection{Exposure to domestic violence as child abuse}

Exposure to domestic violence is the result of children witnessing or hearing physical abuse between their parents, and/or observing the effects (Wolak \& Finkelhor, 1998). Research has shown that children who are exposed to domestic violence show similar symptoms and difficulties as do children who are the direct victims of physical violence (Jaffe, Wolfe, Wilson, \& Zak, 1986; Weithorn, 2001). The prevalence of this problem is high; a study of 1581 domestic violence crimes investigated by law enforcement found that $43 \%$ had a child present, and $95 \%$ of those children were exposed to violence (Fusco \& Fantuzzo, 2009). Estimates from the National Survey of Children's Exposure to Violence indicate that between six to $11 \%$ of children across age groups were exposed to family violence (Finkelhor, Turner, Ormrod, Hamby, \& Kracke, 2009; Hamby, Finkelhor, Turner, \& Ormrod, 2011). Children can be directly exposed (e.g., in the room during the act of violence) or indirectly exposed (e.g., changes in parenting due to maternal depression) (BairMerritt, Zuckerman, Augustyn, \& Cronholm, 2013). Two meta-analyses have shown that children exposed to domestic violence exhibit worse problems than those who are not exposed (Kitzmann, Gaylord, Holt, \& Kenny, 2003; Wolfe, Crooks, Lee, McIntyre-Smith, \& Jaffe, 2003). Data from the National Crime Victimization Survey shows a higher victimization rate for youth in households with a victimized adult (Mitchell \& Finkelhor, 2001). The extent to which these problems are directly attributable to exposure to domestic violence is more difficult to parse out since there is substantial overlap between exposure and actual child abuse. Estimates are as high as 75\% of children exposed to domestic violence are also maltreated (Osofsky, 2003).

A variety of state statutes attempt to address this problem. One example is allowing evidence that a parent was a perpetrator of domestic violence to be used in custody decisions. Another example is that perpetrators of domestic violence who commit domestic violence acts in front of children receive tougher sentences. While California allows exposure to domestic violence as a factor in determining sentence for assault, in Idaho, domestic violence in front of a child can double a sentence (Jaffe, Crooks, \& Wolfe, 2003). In Utah, committing domestic violence in front of a child two or more times creates a separate criminal offense (Edleson, 2004). Meanwhile, two states have made exposure to domestic violence a form of criminal child abuse for the abusive partner (Jaffe 
et al., 2003), and five states have a separate crime for committing domestic violence in the presence of a child.

Laws criminalizing exposure to domestic violence warrant empirical research. While studies have examined whether exposure to domestic violence causes emotional and physical injury, we found no studies that examined whether criminalizing domestic violence or increasing penalties for committing domestic violence in front of a child improves child outcomes or reduces exposure.

\subsection{Failure to protect}

A controversial statute aimed at reducing child abuse is the crime of failure to protect. This law criminalizes a parent's failure to act when his or her child is abused. Often these cases end up in the media spotlight when a parent, typically a mother, is found to have known and or covered up the abuse of her child. Failure to protect laws have been viewed as counter-productive as they may end up re-victimizing women who themselves are victims of domestic violence (Dunlap, 2004; Jaffe et al., 2003). Every state has a passive requirement for parents to protect children or includes the failure to fulfill his or her duty to protect a child in their child abuse legislation; most of these statutes do not require an affirmative act of neglect or malevolent intent (Enos, 1996; Fugate, 2001). The vagueness of statutory language allows for the prosecution based on failure to protect, even though the statute does not explicitly state failure to protect as a criminal violation.

Some states have begun to change their statutes and departmental policies on failure to protect in order to improve child outcomes. West Virginia has eliminated its failure to protect laws and in its place created a no-fault or co-petition system that allows abusers to be held accountable while increasing the safety for children (Yetter, 2010). By copetitioning with the parent, CPS assists the abused parent in obtaining protection from the abuser. The victim-parent is given their own counsel and keeps legal and physical custody of their children throughout the legal process to give children stability and increased safety (Yetter, 2010). Parental rights also come into play in the removal of children from the home of an abused parent. In a federal court case in New York, a judge ruled that removing children from the home of a parent solely because the mother was a victim of domestic violence violates her rights (Silverman, 2008).

Peer reviewed research on the impact of failure to protect actions does not exist. Similarly, there is no existing research on the policy of allowing a co-petition process, as in West Virginia, for preventing abuse. How this practice works, in effect, is unclear. Research is needed to evaluate whether these criminal statutes deter acts of violence and protect children from abuse and, more important, whether these statutes create better outcomes for the children involved.

\subsection{Alternative response}

In a traditional child protective services framework, after a report of child maltreatment is accepted, the case proceeds on an investigative track or is screened out of the system. While a substantiated case may proceed along a civil route including seeking removal of the child from the home, criminal charges may result should the investigation provide evidence of criminal child maltreatment. Yet, in any scenarios under a traditional framework, service provision is not part of the role of social services, though service recommendations may accompany investigations and escalation of intervention may occur if voluntary compliance does not occur. Differential response systems were developed to incorporate family centered practices into child protective services (Hughes, Rycus, Saunders-Adams, Hughes, \& Hughes, 2013). Lower risk families are diverted into an assessment track in an attempt to enhance a parent's ability to safely care for their children (Hughes et al., 2013). Alternative response systems-also known as differential response, dual track, multiple track, or family assessment-allow state child protective services to provide different responses to reports of child maltreatment (Merkel-Holguin, 2005). The additional pathways created include an investigative track, family assessment track, and screened-out, and are designed to provide services to high-risk families. In alternative response, the investigative track is primarily used for severe cases while the family assessment track is used to engage families in services on a voluntary basis who are at low to moderate risk of child maltreatment (Hughes et al., 2013). To date, almost all states have implemented some type of alternative response system (Jones, 2015). However, recent research demonstrates that widespread adoption does not equal consistent design; there is wide variation in definition, design, and implementation across states (Hughes et al., 2013).

Outcome measures used to study alternative response programs include re-reports of child abuse, rates of child abuse substantiation, and removal from home. All but one study examining re-reports of child abuse have found reductions when an alternative response program was present (English, Wingard, Marshall, Orme, \& Orme, 2000; Lawrence, Rosanbalm, \& Dodge, 2011; Loman, Filonow, \& Siegel, 2010; Loman \& Siegel, 2004, 2005; Ruppel, Huang, \& Haulenbeek, 2011). Others have found no significant difference in re-reports of abuse (Shusterman, Fluke, Hollinshead, \& Yuan, 2005) or in the timing of rereports (Conley \& Duerr Berrick, 2010). Additionally, there is a randomized clinical trial being conducted by the National Quality Improvement Center on Differential Response in Child Protective Services in a statewide implementation in Illinois, in five counties in Colorado, and in six counties in Ohio. A recent review of studies concluded that alternative response does not jeopardize child safety and is related to increased family engagement and case worker satisfaction (Kyte, Trocme, \& Chamberland, 2013). One study also found that in states with alternative response systems, fewer cases ended up on the investigative track. Of the cases that did end up on the investigative track, prosecution was more likely to occur (Loman, 2005).

\subsection{Representation of children in child maltreatment proceedings}

In family law cases, children are not typically the named party, yet they are the true party of interest in the litigation. That is, in cases of child abuse, neglect, and custody disputes, the child is the party that will face the direct effects of court decisions. To ensure the child's interests are represented, there are statutes requiring children be provided representation during court proceedings. The benefits of legal representation for a child in these proceedings are undisputed (Duquette \& Darwall, 2012). ${ }^{2}$ This representation can take the form of a guardian ad litem (or an attorney functioning as a guardian ad litem), an attorney (either client-directed or best-interest), or a court-appointed special advocate (CASA) (Atwood, 2008; Child Welfare Information Gateway, 2014c).

The Federal Child Abuse Prevention and Treatment Act (CAPTA), enacted in 1974 and reauthorized in 1996 and 2010, requires states to submit to the Secretary of the U.S. Department of Health and Human Services a written plan for improving the state's child protective services to be eligible for federal funding (Duquette \& Darwall, 2012). The plan must include a provision for appointing representation for children in every maltreatment case that result in a judicial proceeding (Child Welfare Information Gateway, 2014c). States vary in the kinds of professionals who are appointed, in part because the provisions of CAPTA have changed; in 1974, the requirement was for a guardian ad litem, while in 1996 it allowed a lawyer to serve as the guardian ad litem (Duquette \& Darwall, 2012). Most states use a guardian ad litem, while other states allow for either a guardian ad litem or an attorney serving as one, with a minority of states using a court appointed special advocate (CASA) (Atwood, 2008; Glynn, 2006).

\footnotetext{
2 For an in depth discussion of the benefits of legal representation for children, please see work by Duquette and Darwall (2012) and the website of the National Quality Improvement Center on the Representation of Children in the Child Welfare System (NQIC) http://www.improvechildrep.org.
} 
With variation in each state statute, there has been uncertainty and confusion regarding the roles of individuals representing children. When a lawyer is the child's representative, there are unique challenges related to their ethical duties of effective representation, e.g., the child has not selected the attorney, may not understand the attorney's role, and may lack the capacity to tell the attorney their wishes (Lehrmann, 2010). Various professional organizations have attempted to clarify the role of attorneys who represent children in maltreatment cases, including the American Bar Association, the National Association for the Counsel for Children, and the American Association of Matrimonial Lawyers (Duquette \& Darwall, 2012; Elrod, 2003).

While several organizations have attempted to clarify the role and function of a child's representative in these court proceedings, consensus has not been achieved (Duquette \& Darwall, 2012). There is little evidence to suggest which model yields the best results in terms of reduced number of foster care placements and time in placements, reunification rates, or increased permanency. However, there is a substantial body of professional literature written for attorneys regarding the role of a legal representative for children, the necessity for appointing legal representation for children in child maltreatment cases, and relevant statutes and policies. ${ }^{3}$ However, this research does not have an empirical foundation. The National Quality Improvement Center on Legal Representation of Children (NQIC) has also reviewed existing empirical evidence on this topic. Their work found fourteen empirical studies, only one of which used random assignment (Abramson, 1991). Abramson (1991) focused on minority children and found higher rates of reunification and adoption for the CASA group compared to the control. The remaining thirteen studies were either quasi-experimental or descriptive. Of these, one is a study on the caseloads of guardian ad litems in California (Judicial Council of California, 2004) while another looks at the roles of legal representation for children in Germany (Stōtzel \& Fegert, 2006).

Several outcomes have been studied. Relative to child maltreatment cases without legal representation, cases with legal representation were more likely to result in permanency (Calkins \& Millar, 1999; Zinn \& Slowriver, 2008) and children being reunited with their parent (s) (Calkins \& Millar, 1999; Leung, 1996). Three studies found that children with CASA volunteers had fewer placements overall (Calkins \& Millar, 1999; Goodman, Edelstein, Mitchell, \& Myers, 2008; Litzelfelner, 2000). However, results from Leung (1996) do not support a finding of fewer placements. Several studies have found that children with a CASA volunteer have reduced time in out-of-home placements (Leung, 1996).

Several descriptive studies on this topic have found that children with a CASA volunteer receive more services than children with a staff attorney as their representative (Poetner \& Press, 1990). Even when matched by age, gender and type of maltreatment, children with CASA volunteers received significantly more services, on average, than those without (Litzelfelner, 2000). Other descriptive studies simply document the process for appointing, training, and the roles of CASAs or guardian ad litems (Berliner, Fitzgerald, \& Alving, 1998; Hess, Swanke, \& Batson, 2007; Lukowski \& Davies, 2002; Pitchal, Freundlich, \& Kendrick, 2009).

To better understand how various forms of representation affect children, additional outcome measures could be studied such as child well-being comparisons (using school performance or health data), parental criminal recidivism rates, re-reports of maltreatment, and length of time from entry into the court system until case resolution. The NQIC is currently conducting a random assignment experiment in Georgia and Washington State to examine legal representation in child welfare cases (Duquette \& Darwall, 2012). Using a best practices model, the NQIC study will examine whether adherence to this model improves child welfare outcomes.

\footnotetext{
${ }^{3}$ For a summary of the academic literature on this topic, see (QIC-ChildRep, 2015).
}

\section{Conclusion}

This literature review examined eight legal levers and found gaps between the laws that have been implemented and the empirical evidence on their effectiveness. The existing research offers some encouragement that legal levers can alter how the system operates but generally do not inform as to whether child maltreatment has been reduced and/or whether children's long-term outcomes are improved. For example, research on mandatory reporting suggests that mandatory reporting laws do increase the number of cases that are referred, but not offer evidence of whether or not children's outcomes are better. Similarly, evidence suggests that family drug treatment courts improve reunification rates, but do not currently offer sufficient information on the long-term outcomes of children whose parents participated in such a court.

For future research to understand how the legal system affects child maltreatment, it would be insightful to consider both the mechanisms that the law is designed to target and the type of actor whose behavior is targeted. Such inquiry might improve our understanding of what sorts of behaviors are malleable to changes in criminal laws and penalties (i.e. deterrence theory) and what behaviors require service interventions for meaningful change to occur. Criminalizing domestic violence that occurs in front of a child or creating a crime for failure to protect may not be the ideal agent of change as there are many factors that go into a decision to abuse, e.g., addiction, anger control, mental illness, etc. These types of laws rely on criminal deterrence theory and aim to alter the behavior of potential perpetrators of child maltreatment. However, laws that may be more effective in creating a shift in practice could be assessing penalties (criminal or otherwise) to doctors or educators that fail to report child abuse. This type of behavioral shift requires new practice guidelines in an institutional way, and relies less on individual characteristics. In the same way, laws change the interactions at-risk families have with providers may be more effective in effecting change, e.g., alternative response and family drug treatment courts work to improve service delivery in families where maltreatment is suspected or substantiated.

For many reasons, empirical research on the consequences of child maltreatment laws is lacking. Systematic documentation of law at the local, state, and federal levels is absent. Moreover, how agencies interpret, implement, and enforce the law varies across jurisdictions. Incidents of child maltreatment may go undetected or may present in unclear ways in multiple disconnected systems-e.g. health services use for injuries, sexually transmitted infections, emotional disorders; fatalities, acting out behaviors in school discipline or justice records.

Several existing datasets allow researchers to study some factors associated with laws related to child maltreatment: state and county administrative datasets, the National Survey of Child and Adolescent Well-being (NSCAW), Longitudinal Studies of Child Abuse and Neglect (Longscan), the National Incidence Study of Child Abuse and Neglect (NIS), Fragile Families and Child Wellbeing to name a few. Yet, these data have limitations. Administrative data often track only a single agency's work, are rarely designed to track families (rather than just individuals), may track information in non-comparable ways as other jurisdictions, may not be designed for research, and may not be available to researchers. Several national longitudinal datasets track families over time such as Fragile Families and Child Wellbeing and NSCAW. Despite their virtues, a key limitation is that they track a single cohort of individuals over time and therefore comparable information on similarly aged individuals is not available to allow for examination of pre- and posttests or within sample designs. Studying variation across jurisdictions may not be possible because geographic identifiers are often suppressed to protect respondent confidentiality.

Despite these challenges, better understanding how laws affect child maltreatment perpetration, victimization, and subsequent recovery is warranted due to the prevalence and associated harms. This review did not consider every potentially relevant legal lever and there are 
additional areas where research is needed. For example, we did not examine termination of parental rights, however this has implications for parent's constitutional rights and children's welfare. Other areas of research that may warrant examination are state statutes that govern when a child is removed from the home and dictates when they are returned. Additionally, the intersection between domestic violence and child welfare is important and complex. Domestic violence protection orders are another legal lever with the potential to prevent child maltreatment. We also did not discuss the distinction between abuse and neglect. While abuse cases may get more attention in the press and political arenas, neglect cases constitute three-quarters of CPS caseloads. Therefore, better understanding of how laws may prevent neglect may be particularly important from a public health perspective.

\section{Acknowledgments}

This research was supported in part by grant 24452 from the Robert Wood Johnson Foundation. There are no conflicts of interest to be reported with this manuscript.

\section{References}

Abramson, S. (1991). Use of court-appointed advocates to assist in permanency planning for minority children. Child Welfare, 70(4), 477-487.

Ainsworth, F. (2002). Mandatory reporting of child abuse and neglect: Does it really make a difference? Child \& Family Social Work, 7(1), 57-63.

American University School of Public Affairs. (2012, Nov 30). BJA drug court technical assistance/clearinghouse project summary of drug court activity by state and county juvenile/family drug courts. From http://www1.spa.american.edu/justice/documents/ 2153.pdf.

Ashford, J. B. (2004). Treating substance-abusing parents: A study of the Pima County family drug court approach. Juvenile and Family Court Journal, 55(4), 27-37.

Atwood, B. A. (2008). The uniform representation of children in abuse, neglect, and custody proceedings act: Bridging the divide between pragmatism and idealism. Family Law Quarterly, 42(1), 63-101.

Bair-Merritt, M., Zuckerman, B., Augustyn, M., \& Cronholm, P. F. (2013). Silent victims-An epidemic of childhood exposure to domestic violence. The New England Journal of Medicine, 369(18), 1673-1675.

Berliner, L., Fitzgerald, M., \& Alving, M. (1998). Court appointed special advocates for children in Washington state: A review of effectiveness. Washington State Institute for Public Policy.

Besharov, D. J. (1985). "Doing something” about child abuse: The need to narrow the grounds for state intervention. Harvard Journal of Law and Public Policy, 8(3) 539-589.

Boles, S. M., Young, N. K., Moore, T., \& DiPirro-Beard, S. (2007). The Sacramento Dependency Drug Court: Development and outcomes. Child Maltreatment, 12(2), 161-171.

Brezina, T. (1999). Teenage violence toward parents as an adaptation to family strain: Evidence from a national survey of male adolescents. Youth E' Society, 30(4), 416-444.

Bruns, E. J., Pullmann, M. D., Weathers, E. S., Wirschem, M. L., \& Murphy, J. K. (2012). Effects of a multidisciplinary family treatment drug court on child and family outcomes: Results of a quasi-experimental study. Child Maltreatment, 17(3), 218-230. http://dx.doi.org/10.1177/1077559512454216.

Burrus, S., Wagenaar, A. C., Swanson, J., Ibrahim, J. K., Wood, J., \& Mello, M. M. (2010). Making the case for laws that improve health: A ramework for public health law research. Milbank Ouarterly, 88(2), 169-210.

Burrus, S. W. M., Mackin, J. R., \& Finigan, M. W. (2011). Show me the money: Child welfare cost savings of a family drug court. Juvenile and Family Court Journal, 62(3), 1-14.

Bussmann, K. -D. (2004). Evaluating the subtle impact of a ban on corporal punish-ment of children in Germany. Child Abuse Review, 13(5), 292-311.

Calkins, C. A., \& Millar, M. (1999). The effectiveness of court appointed special advocates to assist in permanency planning. Child and Adolescent Social Work Journal, 16(1), $37-45$

Child Welfare Information Gateway (2014a). Establishment and maintenance of central registries for child abuse reports. Washington DC: U.S. Department of Health and Human Services-Children's Bureau.

Child Welfare Information Gateway (2014b). Mandatory reporters of child abuse and neglect. Washington, DC: U.S. Department of Health and Human Services- Children's Bureau.

Child Welfare Information Gateway (2014c). Representation of children in child abuse and neglect proceedings. Washington, DC: U.S. Department of Health and Human ServicesChildren's Bureau.

Chuang, E., Moore, K., Barrett, B., \& Young, M. S. (2012). Effect of an integrated family dependency treatment court on child welfare reunification, time to permanency and reentry rates. Children and Youth Services Review, 34(9), 1896-1902.

Conley, A., \& Duerr Berrick, J. (2010). Community-based child abuse prevention: Outcomes associated with a differential response program in California. Child Maltreatment, 15(4), 282-292.
Dakof, G. A., Cohen, J. B., Henderson, C. E., Duarte, E., Boustani, M., Blackburn, A., ... Hawes, S. (2010). A randomized pilot study of the Engaging Moms Program for family drug cour. Journal of Substance Abuse Treatment, 38(3), 263-274.

Davidson, H. A. (1997). Legal aspects of corporal punishment in the home: When does physical discipline cross the line to become child abuse? Children's Legal Rights Journal, 17, 18.

Davidson, H. A. (1999). Child protection policy and practice at centrury's end. Family Law Ouarterly, 33(3), 765-782.

Dingwall, R., Eekelaar, J., \& Murray, T. (Eds.). (1995). The protection of children: State intervention and family life (Second ed.). Aldershot: Avebury.

Dunlap, J. A. (2004). Sometimes I feel like a motherless child: The error of pursuing battered mothers for failure to protect. Loyola Law Review, 50, 565-622.

Duquette, D. N. (1997). Lawyers' roles in child protection. In M. E. Helfer, R. S. Kemps, \& R. D. Krugman (Eds.), The battered child (5th ed.). Chicago: University of Chicago Press.

Duquette, D. N., \& Darwall, J. (2012). Child representation in America: Progress report from the national quality improvement center. Family Law Quarterly, 46(1), 87-137.

Durrant, J. E. (1999). Evaluating the success of Sweden's corporal punishment ban. Child Abuse \& Neglect, 23(5), 435-448.

Eckrich, J., \& Loudenburg, R. (2012). Answering the call: Drug courts in South Dakota. South Dakota Law Review, 57(2), 171-187.

Edleson, J. L. (2004). Should childhood exposure to adult domestic violence be defined as child maltreatment under the law? In: P.G. Jaffe, L.L. Baker, \& A.J. Cunningham (Eds.), Protecting children from domestic violence: Strategies for community intervention: Guilford Press.

Elrod, L. D. (2003). Raising the bar for lawyers who represent children: ABA standards of practice for custody cases. Family Law Ouarterly, 37(2), 105-129.

English, D. J., Wingard, T., Marshall, D., Orme, M., \& Orme, A. (2000). Alternative responses to child protective services: Emerging issues and concerns. Child Abuse \&' Neglect, 24 (3), 375-388.

Enos, V. P. (1996). Prosecuting battered mothers: State laws' failure to protect battered women and abused children. Harvard Women's Law Journal, 19, 229-268.

Fallon, B., Trocme, N., Fluke, J. D., MacLaurin, B., Tonmyr, L., \& Yuan, Y. -Y. T. (2010). Methodological challenges in measuring child maltreatment. Child Abuse E' Neglect, 34(1), 70-79.

Finkelhor, D., Turner, H., Ormrod, R., Hamby, S., \& Kracke, K. (2009). Children's exposure to violence: A comprehensive national survey. Office of Justice Programs: U.S. Department of Justice.

Foss, R. D., Feaganes, J. R., \& Rodgman, E. A. (2001). Initial effects of graduated driver licensing on 16-year-old driver crashesin North Carolina. Journal of the American Medical Association, 286(13), 1588-1952.

Fugate, J. A. (2001). Who's failing whom? A critical look at failure-to-protect laws. New York University Law Review, 76, 272-308.

Fusco, R. A., \& Fantuzzo, J. W. (2009). Domestic violence crimes and children: A population-based investigation of direct sensory exposure and the nature of involvement. Children and Youth Services Review, 31(2), 249-256.

Gershoff, E. T. (2002). Corporal punishment by parents and associated child behaviors and experiences: A meta-analytic and theoretical review. Psychological Bulletin, 128 (4), 539-579.

Gifford, E. J., Eldred, L. M., Vernerey, A., \& Sloan, F. A. (2014). How does family drug treatment court participation affect child welfare outcomes? Child Abuse E Neglect, 38 (10), 1659-1670.

Glynn, G. F. (2006). The child's representation under capta: It is time for enforcement. Nevada Law Journal, 6, 1250-1262.

Goodman, G. S., Edelstein, R. S., Mitchell, E. B., \& Myers, J. E. B. (2008). A comparison of types of attorney representation for children in California juvenile court dependency cases. Child Abuse \&' Neglect, 32, 497-501.

Green, B. L., Furrer, C., Worcel, S., Burrus, S., \& Finigan, M. W. (2007a). How effective are family treatment drug courts? Outcomes from a four-site national study. Child Maltreatment, 12(1), 43-59.

Green, B. L., Furrer, C. J., Worcel, S. D., Burrus, S. W., \& Finigan, M. W. (2009). Building the evidence base for family drug treatment courts: Results from recent outcome studies. Drug Court Review, 6(2), 53-82.

Green, B. L., Rockhill, A., \& Furrer, C. (2007b). Does substance abuse treatment make a difference for child welfare case outcomes? A statewide longitudinal analysis. Children and Youth Services Review, 29(4), 460-473.

Grogan-Kaylor, A. (2004). The effect of corporal punishment on antisocial behavior in children. Social Work Research, 28(3), 153-162.

Gunnoe, M. L., \& Mariner, C. L. (1997). Toward a developmental-contextual model of the effects of parental spanking on children's aggression. Archives of Pediatrics and Adolescent Medicine, 151(8), 768-775.

Hamby, S., Finkelhor, D., Turner, H., \& Ormrod, R. (2011). Children's exposure to intimate partner violence and other family violence. U.S. Department of Justice, Office of Justice Programs.

Harper, S., Strumpf, E. C., Burris, S., Smith, G. D., \& Lynch, J. (2014). The effect of mandatory seat belt laws on seat belt use by socioeconomic position. Journal of Policy Analysis and Management, 33(1), 141-161.

Hess, C., Swanke, S., \& Batson, A. (2007). An evaluation of the North Dakota guardian ad litem project: $H B$ consultation and evaluation associates.

Hughes, R. C., Rycus, J. S., Saunders-Adams, S. M., Hughes, L. K., \& Hughes, K. N. (2013). Issues in differential response. Research on Social Work Practice, 23(5), 493-520.

Jaffe, P. G., Crooks, C. V., \& Wolfe, D. A. (2003). Legal and policy responses to children exposed to domestic violence: The need to evaluate intended and unintended consequences. Clinical Child and Family Psychology Review, 6(3), 205-213.

Jaffe, P. G., Wolfe, D., Wilson, S., \& Zak, L. (1986). Similarities in behavioral and social maladjustment among child victims and witnesses to family violence. American Journal of Orthopsychiatry, 56(1), 142.

Jones, A. S. (2015). Implementation of differential response: A racial equity analysis. Child Abuse E' Neglect, 39, 73-85. 
Judicial Council of California (2004). Court-appointed counsel: Caseload standards, service delivery models, and contract administration (action required). Center for Families, Children \& the Courts.

Kalichman, S. C., \& Brosig, C. L. (1992). The effect of statutory requirements on child maltreatment reporting: A comparison of two state laws. American Journal of Orthopsychiatry, 62(2), 284-296.

Kim, S. C., Gostin, L. O., \& Cole, T. B. (2012). Child abuse reporting: Rethinking child protection. Journal of the American Medical Association, 308(1), 37-38.

Kitzmann, K. M., Gaylord, N. K., Holt, A. R., \& Kenny, E. D. (2003). Child witnesses to domestic violence: A meta-analytic review. Journal of Consulting and Clinical Psychology, 71(2), 339-352.

Kyte, A., Trocme, N., \& Chamberland, C. (2013). Evaluating where we're at with differential response. Child Abuse \& Neglect, 37(2-3), 125-132.

Lansford, J. E., Sharma, C., Malone, P. S., Woodlier, D., Dodge, K. A., Oburu, P., ... Di Giunta, L. (2014). Corporal punishment, maternal warmth, and child adjustment: A longitudinal study in eight countries. Journal of Clinical Child \& Adolescent Psychology, 43(4), 670-685.

Larzelere, R. E., \& Kuhn, B. R. (2005). Comparing child outcomes of physical punishment and alternative disciplinary tactics: A meta analysis. Clinical Child and Family Psychology Review, 8(1), 1-37.

Lawrence, C. N., Rosanbalm, K. D., \& Dodge, K. A. (2011). Multiple response system: Evaluation of policy change in North Carolina's child welfare system. Children and Youth Services Review, 33(11), 2355-2365.

Lehrmann, D. H. (2010). Advancing children's rights to be heard and protected: The model representation of children in abuse, neglect, and custody proceedings act. Behavioral Sciences \&' the Law, 28(4), 463-479.

Leung, P. (1996). Is the court appointed special advocate program effective? A longitudinal analysis of time involvement and case outcomes. Child Welfare, 75(3), 269-284.

Levy, D. T., Benjakul, S., Ross, H., \& Ritthiphakdee, B. (2008). The role of tobacco control policies in reducing smoking and deaths in a middle income nation: Results from the Thailand SimSmoke simulation model. Tobacco Control, 17(1), 53-59.

Litzelfelner, P. (2000). The effectiveness of CASAs in achieving positive outcomes for children. Child Welfare, 79(2), 179-193.

Loman, L. A. (2005). Differential response improves traditional investigations: Criminal arrests for severe physical and sexual abuse. Institute of Applied Research.

Loman, L. A., Filonow, C. S., \& Siegel, G. L. (2010). Ohio alternative response pilot project evaluation. Final report (pp. 1-173).

Loman, L. A., \& Siegel, G. L. (2004). Differential response in Missouri after five years final report, $1-85$.

Loman, L. A., \& Siegel, G. L. (2005). Alternative response in Minnesota: Findings of the program evaluation. Protecting Children, $20(2$ \& 3), 78.

Lukowski, G. A., \& Davies, H. J. (2002). A challenge for change: Implementation of the Michigan lawyer-guardian ad litem statute: American Bar Association Center on Children and the Law.

MacMillan, H. L., Boyle, M. H., Wong, M. Y. -Y., Duku, E. K., Fleming, J. E., \& Walsh, C. A. (1999). Slapping and spanking in childhood and its association with lifetime prevalence of psychiatric disorders in a general population sample. Canadian Medical Association Journal, 161(7), 805-809.

Malcolm, M., \& Dugda, G. (2012). Child abuse: Does public enforcement crowd out private vigilance? Economics Letters, 114(1), 106-108.

Mannix, R., Fleegler, E., Meehan, W. P., Schutzman, S. A., Hennelly, K., Nigrovic, L., \& Lee, L. K. (2012). Booster seat laws and fatalities in children 4 to 7 years of age. Pediatrics, 130(6), 996-1002.

Masten, S. V., Foss, R. D., \& Marshall, S. W. (2011). Graduated driver licensing and fatal crashes involving 16-to 19-year-old drivers. Journal of the American Medical Association, 306(10), 1098-1103. http://dx.doi.org/10.1001/jama.2011.1277.

Matthews, P., \& Kenny, M. (2008). Mandatory reporting legislation in the United States, Canada, and Australia: A cross-jurisdictional review of key features, differences, and issues. Child Maltreatment, 13(1), 50-63.

Mello, M., Studdert, D. M., \& Brennan, T. A. (2006). Obesity-The new frontier of public health law. The New England Journal of Medicine, 354(24), 2601-2610.

Melton, G. B. (2005). Mandated reporting: A policy without reason. Child Abuse E' Neglect, 29(1), 9-18.

Mensah, G. A., Goodman, R. A., Zaza, S., Moulton, A. D., Kocher, P. L., Dietz, W. H., ... Marks, J. S. (2004). Law as a tool for preventing chronic diseases: Expanding the spectrum of effective public health strategies. Preventing Chronic Disease, 1(1), 1-8.

Merkel-Holguin, L. (2005). Differential response: A common sense reform in child welfare. Protecting Children, 20(2-3), 2-3.

Miller, W. T. (2011). The central registry statute for abuse and neglect matters is constitutionally flawed. Rutgers Journal of Law and Publc Policy, 8(3), 651-673.

Mitchell, K. J., \& Finkelhor, D. (2001). Risk of crime victimization among youth exposed to domestic violence. Journal of Interpersonal Violence, 16(9), 944-964.

National Quality Improvement Center on Differential Response in Child Protective Services (2009s). Differential response in child protective services: A legal analysis, 1-31.

National Quality Improvement Center on Differential Response in Child Protective Services (2010s). Differential response approach in child protective services: An analysis of state legislative provisions. National Quality Improvement Center on Differential Response in Child Protective Services, 1-12.

National Quality Improvement Center on Differential Response in Child Protective Services (2011s). Differential response in child protective services: A guide for judges and judical officers. National Quality Improvement Center on Differential Response in Child Protective Services, 1-14.

National Quality Improvement Center on Differential Response in Child Protective Services (2014s). Final report: QIC-DR cross-site evaluation. Aurora, Colorado: The Kempe Center for the Prevention and Treatment of Child Abuse and Neglect The University of Colorado School of Medicine, Department of Pediatrics Anschutz Medical Campus.
Navid, S. (2011). They're making a list, but are they checking it twice? How erroneous placement on child offender databases offends procedural due process. University of California Davis Law Review, 44, 1641-1674.

Nourbakhsh, E., Nugent, R., Wang, H., Cevik, C., \& Nugent, K. (2012). Medical literature searches: A comparison of PubMed and Google Scholar. Health Information and Libraries Journal, 29(3), 214-222.

Osofsky, J. D. (2003). Prevalence of children's exposure to domestic violence and child maltreatment: Implications for prevention and intervention. Clinical Child and Family Psychology Review, 6(3), 161-170.

Palusci, V. J., \& Vandervort, F. E. (2014). Universal reporting laws and child maltreatment report rates in large US counties. Children and Youth Services Review, 38, 20-28.

Pitchal, E. S., Freundlich, M. D., \& Kendrick, C. (2009). Evaluation of the guardian ad litem system in Nebraska: National Association of Counsel for Children.

Poetner, J., \& Press, A. (1990). Who best represents the interests of the child in court? Child Welfare, 69(6), 537-549.

Pollard, D. (2003). Banning child corporal punishment. Tulane Law Review, 77, 575-657.

QIC-ChildRep. (2015). Academic literature. Retrieved June 1, 2015, from http://www. improvechildrep.org/StateofChildRepresentation/AcademicLiterature.aspx.

Ruppel, J., Huang, Y., \& Haulenbeek, G. (2011). Differential response in child protective services in New York State. NY: New York State Office of Children and Family Services. Retrieved October 2, 2012.

Sabotta, E. E., \& Davis, R. L. (1992). Fatality after report to a child abuse registry in Washington state, 1973-1986. Child Abuse E' Neglect, 16(5), 627-635.

Sherman, J. (2011). Procedural fairness for state abuse registries: The case for clear and convincing evidence standard. The Journal of Gender, Race E Justice, 14, 867-899.

Shusterman, G. R., Fluke, J. D., Hollinshead, D. M., \& Yuan, Y. -Y. T. (2005). Alternative responses to child maltreatment: Finding from NCANDS. Protecting Children, 20(2 \& 3), 32.

Silverman, G. B. (2008). Failure to protect. In C. M. Renzetti, \& J. L. Edleson (Eds.), Encyclopedia of interpersonal violence (pp. 234-235). Thousand Oaks, CA: SAGE Publications, Inc.

Simons, R. L., Lin, K. -H., \& Gordon, L. C. (1998). Socialization in the family of origin and male dating violence: A prospective study. Journal of Marriage and Family, 60(2), $467-478$.

Steen, J. A., \& Duran, L. (2014). Entryway into the child protection system: The impacts of child maltreatment reporting policies and reporting system structures. Child Abuse \& Neglect, 38(5), 868-874.

Stormshak, E. A., Bierman, K. L., McMahon, R. J., Lengua, L. J., \& Conduct Problems Prevention Research Group (2000). Parenting practices and child disruptive behavior problems in early elementary school. Journal of Clinical Child Psychology, 29(1), 17-29.

Stōtzel, M., \& Fegert, J. (2006). The representation of the legal interest of children and adolescents in Germany: A study of the children's guardian from a child's perspective. International Journal of Law, Policy, and the Family, 20, 201-224.

Straus, M. A., \& Paschall, M. J. (2009). Corporal punishment by mothers and development of children's cognitive ability: a longitudinal study of two nationally representative age cohorts. Journal of Aggression, Maltreatment \& Trauma, 18(5), 459-483.

Straus, M. A., Sugarman, D. B., \& Giles-Sims, J. (1997). Spanking by parents and subsequent antisocial behavior of children. Archives of Pediatrics and Adolescent Medicine 151(8), 761-767.

Summers, A., Dobbin, S. A., \& Gatowski, S. I. (2008). The state of juvenile dependency court research: Implications for practice and policy. Reno, NV: National Council of Juvenile and Family Court Judges.

Tremper, C., Thomas, S., \& Wagenaar, A. C. (2010). Measuring law for evaluation research Evaluation Review, 34(3), 242-266.

U.S. Advisory Board on Child Abuse and Neglect (1990). Child abuse and neglect: Critical first steps in response to a national emergency. MD: Rockville.

U.S. Department of Health and Human Services (2011). Establishment and maintenance of central registries for child abuse reports. Washington, DC: Administration for Children and Families. Retrieved from https://www.childwelfare.gov/systemwide/laws policies/statutes/centreg.pdf.

U.S. Department of Health and Human Services Administration for Children \& Families Child Welfare Information Gateway. Retrieved November 21, 2014, from http:// www.childwelfare.gov.

University of Illinois at Urbana-Champaign Children and Family Research Center. Differential Response. Retrieved June 8, 2015, from http://www.cfrc.illinois.edu/ differentialresponse.php.

Wallace, J. L., \& Pruitt, L. R. (2012). Judging parents, judging place: Poverty, rurality and termination of parental right. Missouri Law Review, 77(1), 95-147.

Weithorn, L. A. (2001). Protecting children from exposure to domestic violence: The use and abuse of child maltreatment statutes. Hastings Law Journal, 53(1), 1-156.

Whitaker, D. J., Lutzker, J. R., \& Shelley, G. A. (2005). Child maltreatment prevention priorities at the Centers for Disease Control and Prevention. Child Maltreatment, 10(3) 245-259.

Wolak, J., \& Finkelhor, D. (1998). Children exposed to partner violence. In J. L. Janisnski, \& L. M. Williams (Eds.), Partner violence: A comprehensive review of 20 years of research. Thousand Oaks, CA: Sage Publications.

Wolfe, D. A., Crooks, C. V., Lee, V., McIntyre-Smith, A., \& Jaffe, P. G. (2003). The effects of children's exposure to domestic violence: A meta-analysis and critique. Clinical Child and Family Psychology Review, 6, 171-187.

Worcel, S. D., Furrer, C. J., Green, B. L., Burrus, S. W. M., \& Finigan, M. W. (2008). Effects of family treatment drug courts on substance abuse and child welfare outcomes. Child Abuse Review, 17(6), 427-443.

Yetter, K. (2010). Moving beyond "failure to protect" in West Virginia. Retrieved 01/30/ 2014, from http://www.casaforchildren.org/site/c.mtJSJ7MPIsE/b.6279697/k.8D76/ Katheryn_Yetter.htm. 
Zinn, A. E., \& Slowriver, J. (2008). Expediting permanency: Legal representation for foster children in Palm Beach County. Chicago: Chapin Hall Center for Children at the University of Chicago.

Zolotor, A. J. (2014). Corporal punishment. Pediatric Clinics of North America, 61(5), 971-978.
Zolotor, A. J., \& Puzia, M. E. (2010). Bans against corporal punishment: A systematic review of the laws, changes in attitudes and behaviours. Child Abuse Review, 19(4), 229-247. http://dx.doi.org/10.1002/car.1131. 